International Journal of Biology, Pharmacy and Allied Seiences (IJBPAS)

'A Bridge Betueen Caboratory and QRando'

WwW.ibpas.com

\title{
SUBSURFACE WATER QUALITY ANALYSIS IN AND AROUND CHIDAMBARAM TALUK, TAMIL NADU
}

\author{
T. POONKUNDRAN ${ }^{1 *}$ \\ ${ }^{1}$ Asst. Professor, Department of Civil Engineering, Annamalai University, Chidambaram, \\ 608002, Tamil Nadu, India \\ *Corresponding Author Email: tpoonkupoonku@gmail.com
}

Received 25 ${ }^{\text {th }}$ April 2019; Revised $24^{\text {th }}$ May 2019; Accepted 24 ${ }^{\text {th }}$ June 2019; Available online $1^{\text {st }}$ Dec. 2019 https://doi.org/10.31032/IJBPAS/2019/8.12.4870

\begin{abstract}
The assessment of subsurface water quality is very essential for human beings knowing its importance suitability for standard quality analysis in and around Chidambaram Taluk. Subsurface Water samples were collected from 10 different zones of Chidambaram Taluk and analyzed various characteristics of water samples. The results showed that many of the subsurface water sample quality parameters from residential areas above the permissible limits of BIS and WHO.
\end{abstract}

\section{Keywords: Groundwater, Water pollution, BIS, Water quality}

\section{INTRODUCTION}

Subsurface water is very vital source of drinking water for both human being and animal in the world. It is also very essential source of water for the drinking, agricultural and the industrial sector. Being a significant part of the hydrological cycle, water resources depends on the rainfall and natural recharge and artificial recharging methods. Subsurface water standard is mainly depending up on the physical, chemical and biological characteristics of subsurface water. The suitability of subsurface water for various uses mainly depends on quality of subsurface water. Hence protecting the quality of subsurface water is a major concern Packialakshmi, et al., 2011. Water quality assessment is the major important tool for share the information on the qualities of water to the public. It acts as the indicator of the quality of water. The purpose of assessment water quality is to turn multifaceted water quality 
data into simple information that is essential for the public. Many other researchers have conducted a study on subsurface water quality by estimating the water quality index to substantiate the variation of groundwater quality Kumar et al., 2013.

The source and availability of a water supply depends upon the both quality and quantity is very important to human existence. The supply for water has increased over the year by year and this has led to water scarcity in many other part of the world. The situation is aggravated by the problem of contamination or water pollution. India is facing towards a freshwater crisis mainly due to improper miss management of water resources and environmental degradation. This leads to deficiency of access to safe drinking water supply to millions of people. This drinking water crisis is already evident in many parts of India, varying in scale and intensity depending mainly on the time of the year Sundara Kumar, et al., 2010.

If the groundwater is contaminated, its quality cannot be return to its original quality, till stopping the pollutants from the sources. So more attention required to regularly monitor the ground water quality and to device ways and means to protect it Khalid Hameed Lateef., 2011. Water quality index (WQI) is the important tool to give the information on the water quality to the concerned citizens and policy makers. It is an important parameter for the analysis and management of groundwater. WQI is defined as a rating reflecting the composite influence of different quality of water parameters, Ramakrishnaiah, et al., 2009.

\section{MATERIAL AND METHODS}

All the water samples were collected from 2.5 litre clean and dry plastic canes without any air bubble. Then the water samples were analysed in the water analysis laboratory within four hours after sampling without mixing any preservatives. These Water samples were collected in the month of April 2015 to month of April 2016. The water samples temperature were noted in the sampling point itself. The samples were transfer to the laboratory to determine the major characteristics. The physical and chemical characteristics were analysed such as $\mathrm{pH}$, turbidity, calcium, magnesium, iron, fluoride, TDS, Total Hardness, chloride, sodium, potassium, total coliform, using standard methods ISI, 1983; Sing et al., 2008; Dhembare et al., 1998. Based on the analysed data correlation co efficient was calculated by statistical method. Water samples were collected and analyzed as per procedures outlined in IS-2488/IS3025/AWWA/ APHA. Sterilized containers were used for collection of water sample for bacteriological analysis, stored in icebox and transported to the lab for the analysis. The temperature is measured 
using the thermometer and the $\mathrm{pH}$ is measured using the $\mathrm{pH}$ meter. The total dissolved solids are measured by Gravimetric method. Turbidity is measured using an instrument known as nephelometer (Hussain and Hussain., 2004; Shah et al., 2005; APHA 1989). Atomic Absorption Spectrophotometry provides accurate quantitative analyses for metals in waters. Total suspended solids are measured using Gooch Crucible and Total Hardness is measured using Titrimetric (EDTA) method Shyamala et al., 2008; Packialakshmi et al., 2010; Kumar, 1997; Purandara et al., 2003. Sodium, potassium by flame photometer and aluminium, manganese by atomic absorption spectrophotometer method Agbaire et al., 2009; Palanisamy et al., 2007.

\section{RESULTS AND DISCUSSION}

Determination of chemical and physical characteristics of water is very important for the suitability of water for drinking, household uses and industrial. Standards have been laid down by various agencies such as a World health organization, U.S. Environmental protection agency, Bureau of Indian standard and ICMR for drinking water quality for many other uses. The results of the physico-chemical analysis of water samples are shown in Tables 1 and 2. The mean temperature of water samples ranged from 24 to $37^{\circ} \mathrm{C}$. The highest temperature was recorded in the month of June and the lowest temperature was recorded in the month of February. All the water samples were colourless, odourless, tasteless and clear.

Turbidity is the haziness or cloudiness of a fluid caused by individual particles (suspended solids) that are generally invisible to the naked eyes (Mazhar et al., 2013). The turbidity of all water samples ranged from 0.7 to $2.8 \mathrm{NTU}$ (Tables 2). The higher values are observed at station 1 and lowest turbidity was observed at station 3. The analysed values are above the recommended limits (BIS: 10500-1991). Clear water is more appealing to drink; one treatment method is a filtration system. A total dissolved solid is a measure of total concentration of all constituents dissolved in water and has a bearing on its taste color and odour. The TDS values varied from 114 to $388 \mathrm{mg} / \mathrm{L}$ Tables 2. High levels of TDS is not suitable for bathing and washing (Senthilnathan and Parvathavarthini, 2011). It is generally inferior to palatability and may induce an unfavourable physiological reaction in the transient consumer (Dhembare et al., 1998); Sangeetha et al., (2000); Mariappan et al., (2000) observed greater values of TDS than that of ISI standard, the reason may be due to entry of pollutants. 
Table 1: Name of areas from where samples were collected

\begin{tabular}{|c|c|c|}
\hline Station no. & Location & Source \\
\hline $\mathbf{1}$ & Bhuvanagiri & Open Well \\
\hline $\mathbf{2}$ & Chidhambaram & Bore Well \\
\hline $\mathbf{3}$ & Sethiyathope & Bore Well \\
\hline $\mathbf{5}$ & Poonthotham & Bore Well \\
\hline $\mathbf{6}$ & Vakkur & Bore Well \\
\hline 7 & Manjakollai & Bore Well \\
\hline $\mathbf{8}$ & Oodiyur & Bore Well \\
\hline $\mathbf{9}$ & Mirallur & Bore Well \\
\hline 10 & Orathur & Bore Well \\
\hline
\end{tabular}

Table 2: Groundwater quality parameters of the study area

\begin{tabular}{|c|c|c|c|c|c|c|c|c|c|c|c|c|}
\hline $\begin{array}{l}\text { SI. } \\
\text { No }\end{array}$ & Particulars & Unit & 1 & 2 & 3 & 4 & 5 & 6 & 7 & 8 & 9 & 10 \\
\hline 1 & EC & $\begin{array}{c}\mu \mathrm{S} / \\
\mathrm{cm} @ 25\end{array}$ & 730 & 1050 & 875 & 638 & 960 & 1120 & 895 & 1080 & 795 & 1007 \\
\hline 2 & pH & mg/lit & 7.5 & 7.3 & 7.3 & 7.5 & 8.1 & 7.4 & 7.3 & 7.3 & 7.3 & 8.4 \\
\hline 3 & Turbidity & NTU & 0.7 & 2.3 & 2.8 & 2.6 & 1.5 & 2.5 & 1.7 & 0.9 & 1.8 & 1.6 \\
\hline 4 & $\mathrm{Ca}$ & 6 & 31.5 & 37 & 41.4 & 45 & 36.7 & 45.9 & 34.3 & 47 & $\begin{array}{l}44.7 \\
\end{array}$ & 33.8 \\
\hline 5 & Mg & 6 & 26 & 23 & 31 & 25 & 23 & 27 & 32 & 26 & 29 & 30 \\
\hline 6 & $\mathrm{Na}$ & 66 & 13 & 157.6 & 151.4 & 142.5 & 123.7 & 160.4 & 173.5 & 167.1 & 138.8 & 129.1 \\
\hline 7 & $\mathbf{K}$ & 66 & 25.7 & 9.3 & 5.7 & 6.2 & 5.4 & 6.6 & 5.9 & 15.4 & 12.8 & 9.5 \\
\hline 8 & $\mathrm{HCO}_{3}$ & 66 & 248 & 756 & 978 & 1101 & 850 & 1459 & 1006 & 1270 & 1456 & 960 \\
\hline 9 & $\mathrm{CO}_{3}$ & “6 & 0 & $\mathbf{0}$ & $\mathbf{0}$ & $\mathbf{0}$ & $\mathbf{0}$ & 0 & 0 & $\mathbf{0}$ & 0 & $\mathbf{0}$ \\
\hline 10 & $\mathrm{SO}_{4}$ & 6 & 12.8 & 127 & 70.7 & 146 & 157 & 110 & 90.8 & 89.6 & 134 & 127 \\
\hline 11 & CI & 66 & 28 & 115 & 11.8 & 38.5 & 105 & 242 & 112 & 68.9 & 90.6 & 128 \\
\hline 12 & $\mathrm{NO}_{3}$ & 66 & 5.3 & 5.4 & 4.6 & 4.9 & 5.2 & 7.9 & 6.6 & 5.4 & 5.9 & 6.8 \\
\hline 13 & $\mathbf{F}$ & 66 & 0.46 & 0.77 & 0.65 & 0.56 & 0.48 & 0.61 & 0.59 & 0.89 & 0.77 & 0.69 \\
\hline 14 & TDS & 66 & 114 & 201 & 189 & 267 & 178 & 128 & 301 & 388 & 299 & 198 \\
\hline 15 & $\begin{array}{c}\mathrm{TH} \text { as } \\
\mathrm{CaCO}_{3} \\
\end{array}$ & 66 & 180 & 135 & 122 & 166 & 127 & 160 & 154 & 169 & 140 & 150 \\
\hline 16 & $\begin{array}{c}\mathrm{TA} \text { as } \\
\mathrm{CaCO}_{3} \\
\end{array}$ & & 198 & 127 & 185 & 179 & 132 & 120 & 114 & 110 & 143 & 139 \\
\hline
\end{tabular}

\section{CONCLUSIONS}

Groundwater is essential need for growth of all country. If water resources are to remain available as good quality water for upcomming generations, it is very essential to control from the possible contamination. This freshwater and pure water crisis is already evident in many other part of India, particularly in Tamilnadu, varying in scale and intensity, depending mainly on the climate condition of the year. In Tamil $\mathrm{Nadu}$, water supply scarcity plays an important role. However, water quality monitoring is an important tool to find contamination of groundwater and to provide an advanced warning of the approaching contaminated groundwater to important sources of water supply. This is of great importance, because the problem concerns securing a safe portable water supply for the present and future generation people.

\section{REFERENCES}

[1] Packialakshmi S, Ambujam NK, Nelliyat P. Groundwater market and its implications on water resources and agriculture in the southern periurban interface, Chennai, India. J. Environment, Development and Sustainability. 13(2), 2011, 423-38. 
[2] Kumar S, Bharani R, Magesh NS, Prince Godson S, Chandrasekar N. Hydrogeochemistry and ground water quality appraisal of part of south Chennai coastal aquifers, Tamil Nadu, India using WQI and fuzzy logic method. Applied Water Sciences. 2013; 13-148.

[3] Sundara Kumar K, Sundara Kumar P, Ratnakanth Babu M.J, Hanumantha Rao C, H, Spatial analysis of groundwater quality for virudhunagar district, Tamil nadu using GIS, Int J Eng Sci Technol., 2(11), 2010, 6035-6046.

[4] Khalid Hameed Lateef, Geogenic Assessment of Water Quality Index for the Groundwater in Tiruchengode Taluk, Namakkal District, Tamilnadu, India, Eur J Scic Res., 58(4), 2011, 472-481.

[5] Ramakrishnaiah CR, Sadashivaiah $\mathrm{C}$ and Ranganna $\mathrm{G}$, Assessment of Water Quality Index for the Groundwater in Tumkur Taluk, Karnataka State, India, J Chem., 2009, 6(2), 523-530.

[6] ISI, Indian standard specification for drinking water, IS10500, New Delhi, (1983).

[7] Singh N. B. and Nayal K., Assessment of ground water quality of maraimalai nagar town near Chennai, India, J. Chem., 5(2), 2008, 342-346.

[8] Dhembare A.J, Phonde G. M, Singh C.R. Assessment of ground water quality of maraimalai nagar town near chennai, India, J. Poll. Res., 17(1), 1988, 87-90.

[9] Hussain I, Hussain J, Assessment of ground water quality of maraimalai nagar town near chennai, india, J. Poll. Res., 23(3), 2004, 477-481.

[10] Shah M.C., Prateek S, Sangita S.A. Assessment of ground water quality of maraimalai nagar town near chennai, India, J. Chem., 19(5), 2005 3449-3454.

[11] APHA, Standard methods for the examinations of water and waste water, 18th Ed., American public Health Association, Washington, (1989).

[12] Shyamala R., Shanthi M. and Lalitha P. Assessment of ground water quality of maraimalai nagar town near Chennai, J. Chem., 5(4), 2008, 924-929.

[13] Packialakshmi S, Ambujam NK, Mahalingam S, Emerging land use changes and their effects on groundwater: A study of the Mambakkam mini watershed, Southern Suburban area of Chennai, India, J. Environ. Res. Develop., 5(2), 2010, 340-349. 
[14] Kumar N., A view on Fresh water environment, Ecol. Enc. Cons., 3(1), 1977, 3-4.

[15] Purandara B.K, Varadarajan N, Jayashree K, Assessment of ground water quality of maraimalai nagar town near Chennai, J. Poll. Res., 22(2), 2003, 189-191.

[16] Agbaire P.O, Obj C.G, Assessment of ground water quality of maraimalai nagar town near Chennai, J. App. Sc. Environ. Mgmnt., 13(1), 2009, 55-57.

[17] Palanisamy P.N, Geetha A, Sujatha M, Sivakumar P, Karunakarn K, Assessment of ground water quality in and around gobichettipalayam town erode district, Tamil Nadu. J. Chem., 4(3), 2007, 434-439. 